\title{
Impact on teaching in times of COVID-19 pandemic: A qualitative study
}

\author{
Alejandro Almonacid-Fierro ${ }^{1}$, Rodrigo Vargas-Vitoria ${ }^{2}$, Ricardo Souza De Carvalho ${ }^{3}$, Manuel \\ Almonacid Fierro ${ }^{4}$ \\ ${ }^{1,2,3}$ Faculty of Education, Universidad Católica del Maule, Talca, Chile \\ ${ }^{4}$ Faculty of Education, Universidad Autónoma de Chile, Talca, Chile
}

\begin{tabular}{l} 
Article Info \\
\hline Article history: \\
Received Oct 16, 2020 \\
Revised Mar 15, 2021 \\
Accepted Apr 12, 2021 \\
\hline
\end{tabular}

Keywords:

COVID-19

Physical education

Teachers

Teaching

\begin{abstract}
This article makes an analysis of the pedagogical teaching practices used and developed by Chilean physical education teachers during the coronavirus disease 19 (COVID-19) pandemic periods. The virus from China spread around the world, changed our daily lives and as such, at the same time impacted the educational system in a matter of weeks. Confinement led educational systems to eliminate face-to-face and use virtual teaching in order to continue with the teaching-learning processes, including the physical education discipline. From the methodological point of view, the study is installed in the interpretive-qualitative perspective, in such a way that 14 semi-structured interviews were carried by physical education teachers from the Maule-Chile region, via team, Zoom, Skype, because of the pandemic, face-to-face contact was impossible. The result of the study shows the impact on the quality of life of teachers and students because of the confinement. The pedagogical reconfiguration that teachers experienced in a matter of days, led them to use different virtual platforms to continue connected with their students, in order to deploy the learning objectives defined by the Chilean Ministry of Education. However, the foregoing shows the scarce possibility of verifying student learning, due to the difficulties of monitoring and feedback.
\end{abstract}

This is an open access article under the CC BY-SA license.

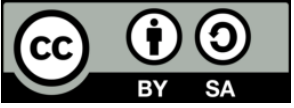

\section{Corresponding Author:}

Rodrigo Vargas-Vitoria

Faculty of Education

Universidad Católica del Maule

Avenida San Miguel 3605, Talca, Chile

Email: rvargas@ucm.cl

\section{INTRODUCTION}

Due to the speed of spread and contamination of the COVID-19 disease at an exponential level, it ended up installing a global pandemic that began in China in late December 2019. Without a vaccine, there were mass confirmed cases around the world and, according to the World Organization of Health (WHO) [1], was configured as a pandemic [1], [2]. The WHO [1] indicated that to effectively combat COVID-19 and preserve lives, countries should isolate the population, avoid crowds, and intensify healthy hygiene habits, such as proper social distancing and hand washing [3]. In educational terms, the classes of children and teenagers in pre-basic, basic and secondary education were suspended indefinitely. The classes of university and graduate students from the universities were also suspended indefinitely. Teachers were exempted from their school and academic activities to carry out remote work, since the policy of most governments was oriented towards the confinement of the population [4]. In this scenario, concerned about the learning gap, parents and schools questioned whether 
students stopped studying, regardless of their age, consequently, a series of measures were adopted to face the educational challenge in times of pandemic [5], [6]

From one moment to another, a multitude of online school activities promoted by teachers was announced, in such a way that teachers make their transmissions online through their channels, platforms or digital social networks. In the midst of social isolation, this phenomenon has mobilized and encouraged thousands of other teachers, until then practically anonymous or with little visibility on the networks, to also produce their didactic performances online [7]. A veritable flurry of debates on any topic invades our network environments and everyone is dedicated to producing and disseminating content for online learning. The lives of teachers reinforce the condition that our connected homes are spaces for teaching and learning. In this way, professors and students enrolled in courses that had previously been attended in person; have migrated to educational activities online [8]. Connected, education professionals produce and distribute content, supervise, guide, evaluate and stimulate their students. Many are rethinking and recreating more seductive and active methodologies, and developing more friendly and interactive digital environments [9], [10].

In the school setting, Physical Education is essential to promote the positive development of schoolage children and is particularly important today, as the world's societies are plagued by a growing incidence of childhood obesity and diseases linked to physical inactivity [11]. Yet despite the alarming decline in children's health documented by research and marketed by the media, society continues to ignore the unfavorable physical education programming offered at the school level. Offering physical education in elementary and middle levels is essential to ensure that children develop the knowledge, fundamental skills and attitude necessary to cultivate a healthy lifestyle at an early age, thus providing them with healthy practices that can later be refined and carried out to adulthood [12]. From a conceptual perspective, Physical Education is not simply a physical activity or a sport; it is an academic subject that must use physical exercise as a vehicle, or means to achieve an educational objective. In this sense, as an integral part of education, physical education will continue to contribute to the growth and integral development of children, mainly through movement with meaning and meaning [13].

The goal of physical education is to help all children develop a healthy lifestyle [14]. More specifically, its importance for children and young people translates into acquiring skills that allow them to perform various physical activities; acquire skills that help them be physically fit; participate regularly in them because they find them pleasant and stimulating. Also, understand and value exercise; understand that physical activity can support self-expression and facilitate social interaction with others; show responsible and social behavior during their development; and showing understanding and respect for all people during physical activity [15]. In school physical education, the activities for the students' practice must be meaningful and developmentally appropriate, according to the age and characteristics of the subject.

Considering the role of the physical education teacher, their practice within the school has always been understood as lacking in education pedagogical kind, considering that their pedagogical action focuses most of the time on procedural aspects, to the detriment of the pedagogical knowledge of the student. Content, reducing teaching to an instrumental didactics [16], [17]. In this sense, the teachers must generate pedagogical/emotional support towards the students and not prioritize the curricular coverage or qualifications. This because, in a context of crisis, the centrality cannot be in the acquisition of knowledge to comply with the national curricular plan, but on the well-being of the students who are educated in the classrooms of schools and high schools in the country [18].

The literature recommends three steps to plan a physical education work session in the times of the COVID-19 pandemic. The first one deals with minimum conditions before the activity, where the guiding principles are established that promote planning and institutional agreements that allow the development of optimal physical education. The second is to have minimum conditions during the activity, here the intention is to learn from inclusive didactic strategies, producing and establishing new behaviors in times of pandemic. The third consists of minimal conditions after physical activity, where there is a return to calm and feedback of behaviors and attitudes in times of pandemic [19], [20]. In this context, teachers in the area are faced with certain obstacles or barriers in order to verify achievements and progress in their students. In this regard, the COVID-19 Social Table [21], argues that it is essential for Physical Education teachers in schools to analyze the proposed curriculum. This analysis must consider the set of contents and skills indicated, transcends the merely instructional through a perspective that contemplates the whole human being and their environment. All this is aimed to become a contributing to the formation of critical and responsible subjects with their own well-being and health, in close connection with the great purposes of Chilean education embodied in the General Education Law [22].

Physical education in times of pandemic is being a challenge, to which teachers and trainees must adapt and generate strategies that allow students to learn optimally and, consequently, remain physically active [23], [24]. In this context, the purpose of the study is part of the idea of investigating how physical education teachers conceive and deploy teaching processes in a time as complex as the COVID-19 pandemic. The foregoing is justified since discipline in the physical education classroom demands eminently procedural 
competences, which are verified from the corporality of the students. This is precisely the aspect that has been limited by virtual teaching as a result of confinement.

The foregoing leads us to the following research questions: 1) What are the pedagogical strategies of the physical education teacher to develop the discipline in times of a COVID-19 pandemic? 2) What have been the procedures for monitoring, evaluation and feedback of the physical education teacher of his classes in times of pandemic?

\section{RESEARCH METHOD}

This study was ascribed to the qualitative and interpretive paradigm [25], [26], since its objective point to the construction of meanings through the interpretation and understanding of the subjectivities of the knowledge and experiences revealed by teachers of physical education in times of COVID-19. For the methodological design, theoretical sampling was used [27] in which the basic principle is to select cases or groups of cases, according to concrete criteria about their content, instead of using abstract methodological criteria.

\subsection{Data collection tools}

The data collection technique was the semi-structured interview. It was chosen, since its characteristics favor more participative, flexible and close dialogues with the participants, as stated by DiCicco-Bloom, and Crabtree [28]. Before the data collection, the researchers obtained written informed consent to ensure the confidentiality of people's names, considering privacy and emphasizing voluntary participation. Due to the COVID-19 pandemic, the informed consent document was sent by email to the participants prior to the meeting, in such a way that after reviewing and signing they returned the researchers by the same means.

To proceed with the analysis of the collected antecedents, the interviews were transcribed. For data treatment, the NVivo 10 software was used, likewise, the content analysis method was used to extract codes and categories inductively [29]. After completing the data collection process, the interviews were categorized. The categorization process began with the review of the theoretical framework. Using these references to raise the previous categories, and later, the coding process began. The codes link different segments or examples present in the data. Then these fragments of the data are brought in and put together to create categories that we define based on some property. For the treatment of the data, a content analysis has been chosen [30], which comprises three activity streams: the condensation of the data, the presentation of the data and the elaboration/verification of conclusions. The data were analyzed using the inductive logic of theoretical categorization.

\subsection{Participants}

The participants were informed about the purposes of the research and their authorization was requested to record the interview, in order to safeguard the ethical aspects of the study according to the Declaration of Helsinki. The interview was conducted via teams, Zoom or Skype, due to the health emergency that the country is going through. The study data were collected during the months of May and July 2020. The inclusion criteria were: physical education teachers who work in the Maule-Chile region; minimum of two years of professional experience in the school system; teachers of public or private schools, teachers who work in elementary education. As exclusion criteria they were defined; teachers with less than two years of professional experience; general education teachers. Table 1 shows the characteristics of the participants in this study. 
Table 1. Characterization of the participant

\begin{tabular}{ccccc}
\hline No & Gender & Kind of school & Years of experience & Town \\
\hline 1 & Male & Urban-private school & 16 & Linares \\
2 & Male & Urban-private school & 8 & Talca \\
3 & Male & Urban-private school & 7 & Linares \\
4 & Female & Urban-public school & 7 & Cauquenes \\
5 & Male & Rural-public school & 4 & Curicó \\
6 & Male & Rural-public school & 2 & Curicó \\
7 & Female & Urban-private school & 1 & Linares \\
8 & Female & Rural-public school & 15 & San Clemente \\
9 & Male & Urban-public school & 6 & Talca \\
10 & Male & Rural-public school & 6 & Curepto \\
11 & Female & Rural-public school & 6 & Pelarco \\
12 & Female & Urban-private school & 2 & Talca \\
13 & Male & Urban-public school & 2 & Talca \\
14 & Male & Rural-public school & 6 & Molina \\
\hline
\end{tabular}

\section{RESULTS AND DISCUSSION}

Table 2 presents the dimensions, category, descriptions and codes that emerged from the analysis and interpretation of the collected information from the 14 interviews carried out with the physical education teachers.

Table 2. Data systematization matrix

\begin{tabular}{|c|c|c|c|}
\hline Mega category & Previous category & Description & Primary category \\
\hline \multirow{2}{*}{$\begin{array}{l}\text { Physical education in times of } \\
\text { a COVID-19 pandemic }\end{array}$} & $\begin{array}{l}\text { Impact of COVID-19 on } \\
\text { physical education class }\end{array}$ & $\begin{array}{l}\text { Category that refers to the impact } \\
\text { of the pandemic on schools and } \\
\text { the PE sector. }\end{array}$ & $\begin{array}{l}\text { Quality of life } \\
\text { Pedagogical } \\
\text { re-configuration } \\
\text { Social networks }\end{array}$ \\
\hline & Didactic-pedagogical aspects & $\begin{array}{l}\text { Category that addresses PE } \\
\text { teaching in times of COVID-19 }\end{array}$ & $\begin{array}{l}\text { Prioritized content } \\
\text { Evaluative process } \\
\text { Emotional well-being }\end{array}$ \\
\hline
\end{tabular}

The description and interpretation of the categories that were obtained from the analysis of the interviews are presented, as well as the units of analysis (which were extracted from the reports), to account for the category obtained. Each story has a code that expresses the following nomenclature: Interview, paragraph (p) and page (p. N). So, to refer to them within the analysis and in relation to the stories, it is the following: "Textual account extracted from the interview."

\subsection{Impact of COVID-19 on PE - primary category: Quality of life}

In relation to the primary category of quality of life, it emerges from the analysis of the interviews, since the COVID-19 pandemic has strongly impacted people's lives, being understood as the individual's perception of their position in life, in the context of the culture and the value system in which they live and in relation to their objectives, expectations, norms and concerns and therefore there is a strong component of the health dimension in people's quality of life, consequently, the pandemic affects the investigated subjects as:

"Our quality of life has been modified and altered, both for economic reasons and for the possibility of maintaining social ties, we have gone from being eminently social people, to spending a lot of time confined in our homes and with the only possible contact of our circle more intimate and close to the family level. Our habitual life energy has been modified because we cannot deny that our vitality is compromised due to confinement." (Interview 1; p.3; p. 1)

"The impact on the quality of life of children is being really substantial, firstly, due to the reality of homes, small houses, sometimes apartments without space to play, and then due to the psycho-emotional state, due to the sedentary lifestyle that is living by keeping them for a long time in front of a computer." (Interview 12; p.4: p. 2)

A good quality of life related to health is due to several factors, it promotes physiological well-being in aspects such as glucose control, better sleep quality, and improvement of physical capacity. Also the reduction or prevention of some pathologies; such as osteoporosis and postural deviations; psychological well-being in terms of relaxation and reduction of anxiety and stress levels, improvement of mood, cognitive improvements and social well-being [31]. The above mentioned leads to teachers being felt safer, more 
socially integrated and consequently develop their professional practice in a better way. In this sense, the teachers in the interviews report that as a result of the pandemic, their quality of life has been affected in terms of social relationships with their family, friends and students. On the other hand, the adverse effects of the pandemic for some children, in terms of increased sedentary lifestyle and the inability to enjoy games at school and in the neighborhood where they live. This situation sometimes generates overcrowding and a negative psycho-emotional impact, which prevents them from enjoying the multiple benefits of physical activity and exercise as a result of the state of confinement generated by the COVID-19 pandemic [32].

\subsection{Impact of COVID 19 on PE-primary category: Pedagogical reconfiguration}

Since the beginning of this pandemic and with the suspension of face-to-face classes, it became essential to adapt and reinvent ourselves to new forms of communication and delivery of pedagogical support to students. Today, more than ever, we have to experience, in education, times that are essentially digital, the teaching-learning process therefore needs to adapt to the new reality, an issue that is evidenced in the following reports from key informants:

"Physical education teachers have had to reinvent ourselves, because now we do training with costumes, creation of dances, days of riddles and days of conversations, days of cooking, to prepare a fruit smoothie, for example, with the idea of maintaining the contact and the pedagogical relationship with our students." (Interview 10; p.1; p. 5)

"Not only did we have to move to the house, but we had to reinvent everything we were doing and were used to do, and we had to start working from scratch and build from scratch and obviously that allows you to realize the shortcomings that exist in the curriculum." (Interview 4; p.2; p. 27)

"The innovation in new methodologies, I believe that nobody was taught to do classes online or in this way, because nobody ever put themselves in this position." (Interview 5; p.2; p. 34)

The teachers interviewed agree that nobody was prepared for something of this magnitude and therefore they have had to innovate in new methodologies and learn in the distance learning process [33]. Based on the above, it is suggested that the teacher, based on the proposed curricular guidelines, considers previously the social context in which the students are immersed. In this new health emergency scenario, a new role is required for the figure of the teacher since, on the one hand, he ceases to be the central actor and, on the other, his activities change from being directors to being leaders and mediators. Thus, its main function is to be a promoter of learning environments, opening the window to this virtual format in which autonomy and self-direction become the appropriate way to manage the learning process [21]. The use of ICTs in education has been the subject of debate by many professionals in the sector, including the assertion that these resources do not guarantee effective teaching. However today, with the real situation of the COVID-19 pandemic, the choice of whether or not to use digital technologies in the classroom is no longer optional. It is important, therefore, that teachers and students are inserted in the digital environment, which highlights the need to promote digital literacy and consequently a pedagogical reconfiguration by teachers, as mentioned by Ferding, et al. [7]. The foregoing, receives special attention in the area of physical education and health, which is characterized by being eminently experiential and currently has had to move rapidly to virtual teaching environments.

\subsection{Didactic-pedagogical aspects - primary category: Social networks}

Under the context faced as a country, teachers in general have a rather complex and varied work, where the main objective is that all students receive the information, content, and matter in an equitable way, and this is where it can be seen in the stories that social networks and technology take on great importance.

\footnotetext{
"Use of the synchronous video conference resource via Zoom, Google Meet, to carry out Physical Education classes and course meetings ... realization of information capsules on the subject of Physical Education for all grades, delivery of information and practical guides through the WhatsApp application, Messenger, among others." (Interview 9; p.2; p. 36)

"The communication channels with the students, in general, emerge from the didacticmethodological actions carried out, that is, via email and WhatsApp in the feedback of the guides posted in the email box, via the Zoom platform; in the interaction produced during the classes "Online" and during ethical shifts, with those students who are going to remove guides from the Box." (Interview 11; p.3; p. 43)
} 
Social networks in this context have been the most successful means to start a conversation, develop a class or acquire/deliver information to students and parents. It should be noted that WhatsApp, Instagram and Facebook are applications that most know how to use and, on the other hand, do not consume mobile data from the internet plan, being a great support in this contingency. From the literature, it is suggested to use different formats such as Instagram, WhatsApp groups, Zoom, institutional Facebook Fan page, video or stories in blogs, YouTube channel or podcasts developed by students, among others [5]. These changes in a few days indicate that social isolation does not have to be synonymous with suffering and exclusion from the world. On the contrary, our social isolation, marked by these cyber cultural experiences, to face the COVID19 pandemic, can be an interconnected insulation, as shown by various educational experiences carried out during the pandemic [34]. On the other hand, we have observed that physical education teachers approach their pedagogical work through online platforms, but without the need for simultaneous connection. Followed by activities with the supervision of parents, performing regular synchronous online activities, under technological availability of families. They also offer regular asynchronous activities online in relation to the content of the class, in such a way as to attend students in their corporeity learning process [35].

\title{
3.4. Didactic-pedagogical aspects-primary category: Prioritized contents
}

According to the key informants account, we find that the Chilean Ministry of Education prioritizes certain contents that come from the Curricular Bases for the time of the pandemic, the teachers, in general, have been oriented to develop in their classrooms some contents such as:

\begin{abstract}
"We have prioritized physical conditioning because it is a content that can be done in a reduced space, so since you cannot leave the house or you should not and we have a wide margin of space that not everyone has, we have prioritized physical conditioning...exercises of balance, stability, perhaps, despite everything we also work on resistance.... at least we try from fifth to fourth grade is very similar." (Interview 2; p.1; p. 14)

"Regarding what is done by the boys and girls related to the movement and physical activity that they carry out from their homes. Mention that these works are deployed in direct relation to the learning objectives $(L O)$; they are objectives that are decreed in the document of curricular prioritization of the respective subject granted by the Ministry of Education of Chile." (Interview 13; p.3; p. 59)
\end{abstract}

According to the document prepared by the COVID-19 Social Board [21], the global pandemic situation has generated a set of adjustments to educational systems worldwide and Chile has not been the exception. The truncated start of the school year and its adaptation to a remote way has implied emergent actions in order to maintain links and avoid, as far as possible, the interruption of the pedagogical process between teachers and students [18]. In May 2020, the Ministry of Education of Chile proposed a curricular prioritization in which fundamental learning objectives were selected to all areas available on its website [36]. The curricular prioritization has to do with the allocation of higher priority to some skills and content over others. Because they are considered qualitatively more important, of greater utility or of greater training potential, in that the particular case of the area of physical education. According to the report of the teachers interviewed, the prioritization has been oriented to the development of basic motor skills, and those aspects associated with exercise and health.

\subsection{Didactic-pedagogical aspects-primary category: Evaluation process}

According to the interviewees, when trying to evaluate their students they have encountered different realities, problems and circumstances in which they cannot know if they receive the educational content, which they report.

"Concretely, we do not have how to verify that they are doing the exercises and if they are learning some physical conditioning and how to work at home with little space and with little material." (Interview 2; p.3; p. 14)

"The evaluation in times of pandemic that is difficult in my opinion, we in our area is super difficult to evaluate since we do not know if all our students are reviewing the videos and requesting a sample video would be very tedious for them and for us too." (Interview 2; p.3; p. 15)

The period of insecurity and destabilization in which the world lives in the face of the unknown and terrifying COVID-19 had consequences for the evaluation process. Distance education had to be 
implemented in order not to have interruptions in the courses in elementary and secondary school. The aforementioned pandemic has forced the school system to use the long-range social media WhatsApp, Facebook, Instagram and other media instances to stimulate and guide the studies of children and adolescents [6]. This new context undoubtedly makes the act of evaluating even more challenging, since it brings with it the demand to (re) invent an evaluation process that goes hand in hand with a new way of teaching by teachers. In these situations, it is identified that the lack of a means to verify the learning process in students is notorious, since many do not have the resources to access online education in an optimal way. This is essential to overcome difficulties in learning, not having the opportunity to clarify doubts and provide feedback on their progress and setbacks in the discipline [37].

\subsection{Didactic-pedagogical aspects-primary category: Emotional well-being}

Although the current context is limiting us in some pedagogical aspects, it is in this instance, that teachers of all subjects must take advantage of and extract the positive side of all this situation that we live today. It is for this reason that pedagogues adapt and look for the best tools to achieve an optimal teachinglearning process for young people. This is how it can be seen in the following reports from the teachers interviewed and how they have adapted to the current situation in the country.

"In relation to my professional experience during this time, I have had to adjust my work plan, since only instances of classes have been generated from the connection through the use and management of digital platforms and the sending of capsules of information, based on the execution of practical exercises, games and motor challenges of locomotion, manipulation and balance, preferably. So that they do in their homes, considering the time of the pandemic in which we are immersed, however I am concerned about the emotional environment of my students. " (Interview 14; p.3; p. 67)

"From my perspective, I consider that the emotional well-being of children is fundamental in these times of pandemic, and that physical education allows children to fill themselves with positive emotions through physical activity." (Interview 4; p.2; p. 29-30)

In the times of the COVID-19 pandemic, teachers must review the usual forms of teaching, modify pedagogical planning and find alternatives to involve motivate and promote the emotional well-being of students, even at a distance [38]. The teaching profession involves many relationships and perhaps the greatest loss is concentrated in this area. The lack of interactions between teachers and students, as well as between students, is one of the main challenges when adapting classrooms to the effects of the COVID-19 pandemic, since it is necessary to adapt classes, materials and activities to a different model from the traditional classroom [39]. The teachers have had to adapt to the circumstances that the country is going through, that are, to adapt the contents and planned objectives, units to be carried out, proposed activities, among many other things that were had in mind before the pandemic. However, the teacher must go beyond using technological tools to deliver their content; but rather, teachers must develop actions in educational contexts that permanently favor mental, emotional, social and physical well-being. All this to promote in children and young people a pedagogy that, considers individual needs and territories, encourages the challenge and enjoyment of learning and an active and healthy life in interactions based on the care and support of all members of the educational community [21].

\section{CONCLUSION}

The negative effects of the non-existence of physical education classes in times of the COVID-19 pandemic can be summarized in at least two aspects: on the one hand, the issue of physical activity and, on the other, the development of social skills. When identifying and interpreting the pedagogical strategies used by Physical Education teachers in times of pandemic, it can be concluded that this time for the interviewees has been challenging not only on a professional level, since the quality of life of each one of them has been affected by the confinement. On the other hand, came to evidence the great social gap that exists in Chile and affects thousands of families, including those that are part of the institutions where the teachers interviewed in this study work. In relation to their professional performance, it is concluded that teachers have had to innovate in new learning methodologies for which they were not prepared, incorporating technology as one of the main tools to deliver knowledge, mainly through videos and online classes. Those that have allowed the delivery of the contents prioritized by the Ministry of Education of Chile, passing educators from having a central role, to being promoters of learning environments for their students, with interactive environments that are more friendly, flexible and adjusted to the reality of each student. 
In times of crisis we become stronger, in adversity we learn. This is a time of great caution, but also of great hope, and in this sense, collaboration and solidarity have been fundamental so that as a society we can quickly fight against the COVID-19 pandemic, living the paradox of getting closer, even to the distance. In this context, the study allowed us to understand the fundamental role of the physical education teacher, to make the discipline show its relevance and its possibilities, which transcend the walls of the school, since it inexorably affects the lives of children and young people at who educate. In this context, one of the greatest difficulties for teachers has been the difficulty of implementing evaluation processes; the situation in the Physical Education classroom becomes particularly sensitive. It is an area that, along with Arts, present developments preferably in the procedural field, consequently, it has been difficult for professionals in these disciplines to verify the learning of their students in times of pandemic.

In terms of study limitations, it can be pointed out the impossibility of applying a second data collection technique such as the focus group, due to the difficulties of confinement, the time availability of the participants, the problems of internet connection and the inconveniences of researchers themselves to more easily access field work. Consequently, it is necessary to continue investigating with qualitative or mixed techniques, the didactic-pedagogical strategies implemented by the teachers. Also, the development of the learning objectives stipulated in the national curriculum, which has been reconfigured and prioritized by the Ministry of Education of Chile during the COVID-19 pandemic. Finally, one of the suggestions that emerge from this study is related to knowing the opinion of students and their families regarding the teaching and learning processes that they have experienced in 2020, in order to reflect on its impact on life of children and their families.

\section{REFERENCES}

[1] World Health Organization, "Coronavirus disease (COVID-19): situation report-102," 2020. [Onlline]. Available: https://apps.who.int/iris/handle/10665/332055.

[2] C. Sohrabi, et al., "World Health Organization declares global emergency: A review of the 2019 novel coronavirus (COVID-19)," International Journal of Surgery, vol. 76, pp. 71-76, 2020, doi: 10.1016/j.ijsu.2020.02.034.

[3] M. P. Cruz, E. Santos, M. V. Cervantes, and M. L. Juárez, "COVID-19, a worldwide public health emergency," Revista Clínica Española, vol. 221, no. 1, pp. 55-61, Jan. 2021, doi: 10.1016/j.rce.2020.03.001.

[4] F. M. Reimers and A. Schleicher, "A framework to guide an education response to the COVID-19 Pandemic of 2020," OECD, 2020.

[5] J. Reich, et al., "Remote learning guidance from state education agencies during the COVID-19 pandemic: a first look," 2020. [Online]. Available: https://edarxiv.org/437e2/

[6] M. Langford and C. Damsa, Online Teaching in the Time of COVID-19: Academic' Experience in Norway," Centre for Experiential Legal Learning (CELL), University of Oslo, 2020.

[7] R. E. Ferdig, E. Baumgartner, R. Hartshorne, R. Kaplan-Rakowski, and C. Mouza, Teaching, Technology, and Teacher Education during the COVID-19 Pandemic: Stories from the Field. Association for the Advancement of Computing in Education (AACE), 2020. [Online]. Available: https://www.learntechlib.org/p/216903/.

[8] J. Crawford, et al., "COVID-19: 20 countries' higher education intra-period digital pedagogy responses," Journal of Applied Learning \& Teaching, vol. 3, no. 1, pp. 1-20, 2020, doi: 10.37074/jalt.2020.3.1.7.

[9] P. A. Ortiz, "Teaching in the time of COVID-19," Biochemistry and Molecular Biology Education, vol. 48, no. 3, 2020, doi: $10.1002 / \mathrm{bmb} .21348$.

[10] J. Morales, "Oportunidad o Crisis Educativa: Reflexiones desde la Psicología para Enfrentar los Procesos de Enseñanza-Aprendizaje en Tiempos de Covid-19," Revista Internacional de Educación para la Justicia Social, vol. 9, no. 3, 2020. [Online]. Available: https://revistas.uam.es/riejs/article/view/12228.

[11] T. D'Isanto, A. Manna, and G. Altavilla, "Health and physical activity," Sport Science, vol. 10, no. 1, pp.100-105, 2017.

[12] N. Lander, N. Eather, P. J. Morgan, J. Salmon, and L. M. Barnett, "Characteristics of teacher training in schoolbased physical education interventions to improve fundamental movement skills and/or physical activity: A systematic review," Sports Medicine, vol. 47, no. 1, pp. 135-161, 2017, doi: 10.1007/s40279-016-0561-6.

[13] L. Gallo and L. Martínez, "Linhas pegagógicas para Educação Corporal," Cad. Pesqui., vol. 45, no. 157, pp. 612-629, 2015, doi: 10.1590/198053143215.

[14] Ministerio de Educación de Chile, Bases Curriculares Educación Básica. Unidad de Currículum y Evaluación. Decreto Supremo de Educación N433/2012, 2013. [Online]. Available: https://www.bcn.cl/leychile/navegar?idNorma=1047359.

[15] R. Bailey, K. Armour, D. Kirk, M. Jess, I. Pickup, and R. Sandford, "The educational benefits claimed for physical education and school sport: an academic review," Research Papers in Education, vol. 24, no. 1, pp.1-27, 2009, doi: $10.1080 / 02671520701809817$.

[16] I. Kim and B. Ko, "Developing elementary content knowledge in physical education teacher education," International Journal of Human Movement and Sports Sciences, vol. 4, no. 2, pp. 13-19, 2016, doi: 10.13189/saj.2016.040201.

[17] S. J. I. Samuel, M. D. Annamalai, and M. Kumar, "A Study on Evaluating the Pedagogical Knowledge of School Teachers," Journal of Educational and Social Research, vol. 9, no. 3, 194-202, 2019. 
[18] C. Colef, "Recomendaciones docentes para una educación física escolar segura y responsable ante la "nueva normalidad," Minimización de riesgos de contagio de la COVID-19 en las clases de EF para el curso 2020-2021," Revista Española de Educación Física y Deportes, no. 429, pp. 81-93, 2020. [Online]. Available: https://www.reefd.es/index.php/reefd/article/view/902.

[19] C. Kalazich Rosales, "Orientaciones Deporte y COVID-19: Recomendaciones sobre el retorno a la actividad física y deportes, niños, niñas y adolescents," Rev Chil Pediatr., vol. 91, no. 7, pp. 75-90, 2020, doi: 10.32641/rchped.v91i7.2782.

[20] K. Fallon, "Exercise in the time of COVID-19," Australian Journal of General Practice, vol. 49, 2020, doi: 10.31128/ajgp-covid-13.

[21] Mesa Social Covid-19, Didácticas para la proximidad: aprendiendo en tiempos de crisis. Santiago de Chile, 2020. [Online]. Available: http://www.rmm.cl/biblioteca-digital/didacticas-para-la-proximidad-aprendiendo-en-tiemposde-crisis

[22] Ministry of Educationn, Ley 20.370, Ley General de Educación. Santiago, Chile: Diario Oficial de la República de Chile, 2009. [Online]. Available: http://www.leychile.cl/Navegar?idNorma=1006043.

[23] P. Chen, L. Mao, G.P. Nassis, P. Harmer, B. Ainsworth, and F. Li, "Coronavirus disease (COVID-19): the need to maintain regular physical activity while taking precautions," J Sport Health Sci., vol. 9, no. 2, pp. 103-104, 2020, doi: $10.1016 /$ j.jshs.2020.02.001.

[24] E. Isidori, "Sports Pedagogy at the Time of COVID-19," Cultura, Ciencia y Deporte, vol. 15, no. 44, pp. 45-146, 2020, doi: 10.12800/ccd.v15i44.1480

[25] Flick, U, An introduction to qualitative research, 4th ed. Los Angeles, CA: SAGE Publications, 2009.

[26] L. M. Given, The Sage encyclopedia of qualitative research methods. Thousand Oaks, CA: SAGE Publications, 2008.

[27] B. Glaser and A. Strauss, The discovery of grounded theory: strategies for qualitative research. Piscataway, NJ: Aldine Transaction, 1967.

[28] B. DiCicco-Bloom and B. F. Crabtree, "The qualitative research interview," Medical Education, vol. 40, no. 4, pp. 314-321, 2006, doi: 10.1111/j.1365-2929.2006.02418.x.

[29] E. Töre, "The Opinions of Students, Professors and Practice Teachers on the Teaching Practice Course. International Journal of Evaluation and Research in Education (IJERE), vol. 9, no. 1, pp. 10-20, 2020, doi: 10.11591/ijere.v9i1.20363.

[30] M. Gläser-Zikuda, G. Hagenauer, and M. Stephan, "The potential of qualitative content analysis for empirical educational research," Forum Qualitative Sozialforschung/Forum: Qualitative Social Research, vol. 21, no. 1, 2020, doi: 10.17169/fqs-21.1.3443.

[31] M. Karimi and J. Brazier, "Health, health-related quality of life, and quality of life: what is the difference?" Pharmacoeconomics, vol. 34, no. 7, pp. 645-649, 2016, doi: 10.1007/s40273-016-0389-9.

[32] American College of Sport Medicine, "Staying Physically Active During the COVID-19 Pandemic," acsm.org, 2020. [Online]. Available: https://www.acsm.org/read-research/newsroom/news-releases/newsdetail/2020/03/16/staying-physically-active-during-covid-19-pandemic

[33] S.M. Fernandes, L.G. Henn, and L.B. Kist, "O ensino a distância: alguns apontamentos," Research, Society and Development, vol. 9, no. 1, pp. 1-24, 2020, doi: 10.33448/rsd-v9i1.1551.

[34] S. Barrantes, "El ejercicio físico, la actividad física. ¿Cómo continuarlo en tiempo de pandemia?” Rev. Costarric. Cardiol, vol. 22, pp. 27-29, 2020.

[35] V. Varea and G. González-Calvo, "Touchless classes and absent bodies: teaching physical education in times of Covid-19," Sport, Education and Society, pp. 1-15, 2020, doi: 10.1080/13573322.2020.1791814.

[36] Ministerio de Educación, Priorización Curricular: Educación Física y Salud, 2020. [Online]. Available: https://www.curriculumnacional.cl/614/w3-article-177753.html?_external_redirect=articles177753_archivo_01.pdf

[37] T. Fuentes, "Educación física en tiempos de coronavirus y confinamiento: análisis desde la experiencia," EmásF: Revista digital de educación física, vol. 11, no. 65, pp. 151-181, 2020.

[38] E. Couto, E. Couto, and I. Cruz, "Fiqueemcasa: educação na pandemia da covid-19," Interfaces CientíficasEducação, vol. 8, no. 3, pp. 200-217, 2020, doi: 10.17564/2316-3828.2020v8n3p200-217

[39] G. Basilaia and D. Kvavadze, "Transition to Online Education in Schools during a SARS-CoV-2 Coronavirus (COVID-19) Pandemic in Georgia," Pedagogical Research, vol. 5, no. 4, pp. 1-9, 2020, doi: https://doi.org/10.29333/pr/7937. 